\title{
Commentary 10 to the Manifesto for the marine social sciences: the conditions of social science production-a South Asian perspective
}

\author{
Aarthi Sridhar ${ }^{1,2}$ \\ Published online: 3 July 2020 \\ (C) The Author(s) 2020
}

The form of a manifesto is inspired by the context of its emergence. Classics, such as the 1848 Communist Manifesto (Marx and Engels 1967) or more recent ones like the Cyborg Manifesto (Haraway 1991), contain a reflexive exposition of the historical context and pursuits of its principal actors. The comments in this brief note are restricted to contextualizing the social relations and conditions of social scientists mentioned in the present Manifesto for the Marine Social Sciences (MMSS).

\section{A diversity of theories and theorists}

Aristotle's natural and moral philosophy had transformed into distinct scientific pursuits such as natural history, sociology, economics, and psychology by the eighteenth century. The desire to understand the social world in the terms of the natural led to a fashioning of pet methods that aimed at grasping objective and universal truths about society. Maritime social scientists today are divided into those with greater positivist proclivities and those disenchanted with objectivity and creating universalizing claims. This creative tension and the diversity of epistemological beliefs and fetishes have underlined our creative strength and energies. Section 3 of MMSS calls for a range of these methodologies to be put into play. In practice, there are few collaborative projects from South Asia that bring together truly interdisciplinary maritime research. More collaborations can generate diverse accounts of maritime reality, and this scholarly pursuit will help us understand our plural contexts.

Aarthi Sridhar

aarthi77@gmail.com

1 GID, AISSR, University of Amsterdam, Amsterdam, Netherlands

2 Dakshin Foundation, Bengaluru, India

\section{A time for reflexivity in the marine social sciences}

A good deal of social science (happily some of it published in Maritime Studies) is indebted to those early French philosophers who showed administrators, policy-makers, engineers, technologists, and scientists from the physical sciences that all knowledge production about our natural and social world is historically contingent, political, and context-dependent. Indeed, if knowledge about the physical world is not an objective "view from nowhere" (Shapin 1998) then by no means are social scientists, their ideas, or products exceptional in this regard. Pierre Bourdieu's (1977) theory of practice is explicit about the social and historical origins of supposed 'universal' academic ideas and practices. His notion of 'reflexivity' is the sobering reminder the academic scholar needs of the social, historical, political, and psychological contexts that make possible her scholarship. While there is little attention paid to sociologies of knowledge from South Asia, there is even lesser attempt at reflexivity among social scientists more generally, to appreciate the context that gave rise to decades of maritime scholarship and its myriad strains. Such reflection would be vital to account for the genealogies of our epistemic community.

\section{Tackling an unequal research effort}

In the mid-twentieth century, universities in post-colonial nations of South Asia (like India) set up departments in economics, history, and sociology which saw the rise of nationalist scholars and scholarship as a reaction to dominant colonial ideologues and discourses. Since then, the nature, organization, and impacts of the epistemic community of social scientists in India has seen many shifts. Over half a century, South Asian and foreign social scientists, administrators, and 
agencies interested in studying this part of the world have come together in networks, associations, and partnerships. This has resulted in the production of a range of academic ventures including conferences, scholarships, grants, and research projects. However, inequalities in intellectual labour and all forms of capital (financial, social, and cultural) between the global north and the south persist in the academic arena and maritime studies are no exception, as prof. John Kurien's address to the 10th MARE conference reiterated (Bevitt 2019). In India, academic social sciences is still the preserve of the upper caste male. Beyond the university, intellectual work by civil society organizations and social movements only receives opportunistic support or valorization, and here too the gender bias is well-known.

Dedicated effort is needed to check internal processes of marginalization in the social sciences which can render the diverse "tropical majorities" (Kurien 2002) into mere "empirical Shudras" (lower castes) whose only remit is to provide an account of her experience for transformation into elegant theory by "theoretical Brahmins" (high caste) elsewhere (Guru 2002). Serious efforts are needed from social scientists as transformative agents to revise our partnerships and interventions to address systemic inequalities in research. This would give concrete shape to the idea of cognitive justice.

\section{Research in a less-than-tolerant world}

A final but fundamental point to note is that over the last few years, social scientists are increasingly finding themselves in chains. No longer is easy movement across field sites and free expression of ideas and views a taken-for-granted feature of our trade. East or west, north or south, the number of nations restricting the movements, actions, and permits of scholars (local or foreign, social, and natural scientists) on suspicion of threats to sovereignty grows. Our global epistemic community needs to grasp what existential meaning this holds for scholarship and knowledge not just in 'troubled field sites' but for knowledge everywhere.

Open Access This article is licensed under a Creative Commons Attribution 4.0 International License, which permits use, sharing, adaptation, distribution and reproduction in any medium or format, as long as you give appropriate credit to the original author(s) and the source, provide a link to the Creative Commons licence, and indicate if changes were made. The images or other third party material in this article are included in the article's Creative Commons licence, unless indicated otherwise in a credit line to the material. If material is not included in the article's Creative Commons licence and your intended use is not permitted by statutory regulation or exceeds the permitted use, you will need to obtain permission directly from the copyright holder. To view a copy of this licence, visit http://creativecommons.org/licenses/by/4.0/.

\section{References}

Bevitt, K. 2019. Respecting the other: leading practitioner calls for greater research collaboration at MARE conference. [blog post] Retrieved from http://blog.worldfishcenter.org/2019/08/respectingthe-other-leading-practitioner-calls-for-greater-researchcollaboration-at-mare-conference/.

Bourdieu, Pierre. 1977. Outline of a theory of practice. Translated by Richard Nice. Cambridge University Press, Cambridge.

Guru, G. 2002. How egalitarian are the social sciences in India? Economic and Political Weekly: 5003-5009.

Haraway, D. 1991. A cyborg manifesto: science, technology, and socialist feminism in the late twentieth century. In simians, cyborgs, and women: the reinvention of nature. New York: Routledge. First published 1985.

Kurien, J. 2002. People and the sea: a 'tropical-majority' world perspective. Maritime Studies 1 (1): 9-26.

Marx, K., and F. Engels. 1967. The communist manifesto. 1848. Trans. Samuel Moore. London: Penguin.

Shapin, S. 1998. Placing the view from nowhere: historical and sociological problems in the location of science. Transactions of the Institute of British Geographer

Publisher's note Springer Nature remains neutral with regard to jurisdictional claims in published maps and institutional affiliations. 